\title{
LibQUAL Canada 2007: Service Quality Bench-marking on a National Scale
}

\section{Introduction}

The 2007 LibQUAL Canada Consortium was an historic achievement in the development of library assessment practice in Canada. As the largest ever LibQUAL ${ }^{\mathrm{TM}}$ consortium, covering the majority of Canada's university libraries, the LibQUAL Canada Consortium has taken a very large first step in collecting service quality data for benchmarking on a national and regional level. This article outlines the development of the consortium within the national context, what made it successful for its members and its experience with the LibQUAL $+^{\mathrm{TM}}$ survey (what we have learned and where we would like LibQUAL+ ${ }^{\mathrm{TM}}$ to go in the future).

\section{Why not just develop a Canadian survey?}

This question did arise during the initial planning of the consortium. Ultimately, however, LibQUAL+ ${ }^{\mathrm{TM}}$ was the clear choice for the consortium's 2007 survey project. It had been refined and validated over the years with input from participants, focus groups and other analyses. The challenges and costs to build a better Canadian survey instrument and a national support infrastructure such as that provided by ARL for LibQUAL+ ${ }^{\mathrm{TM}}$ participants would be huge. Above all, more Canadian institutions needed some experience with such a program before we could consider engaging in fruitful discussions about alternative assessment directions.

Sixteen Canadian university libraries were already members of the Association of Research Libraries (ARL) and regularly contributed their quantitative data (expenditures, collections, etc.) to ARL's annual member surveys. So, it was natural for Canadian ARL members to adopt the service assessment tool widely used among other ARL libraries, LibQUAL+ ${ }^{\mathrm{TM}}$. Indeed, York University was one of the handful of institutions involved in the initial development of LibQUAL $+^{\mathrm{TM}}$.

\section{LibQUAL ${ }^{\mathrm{TM}}$ and the Canadian Context}

More than 20 Canada university libraries had participated in LibQUAL+ ${ }^{\mathrm{TM}}$ since its inception. However, among the hundreds of mostly American participants, in any given year, there had never been more than ten Canadian participants. The latter fact is crucial to understanding the impetus behind the development of the LibQUAL+ Canada Consortium.

Education in Canada is under provincial jurisdiction and all academic institutions are publicly funded (other than a few small faith-based schools). Public policies, practices and funding relating to higher education have varied widely across Canada. These factors have notably shaped higher education in each province. So, the opportunity for academic libraries to benchmark their services with those of peer institutions in the same provincial/regional jurisdiction was a powerful incentive.

By 2006, LibQUAL+ ${ }^{\mathrm{TM}}$ was the primary instrument used by Canadian academic libraries to assess library service quality, according to a recent study of assessment practices in Canadian university libraries by Jordan and McKennai. In fact, the study found that LibQUAL $+^{\mathrm{TM}}$ was the first, and in many cases the only, systematic service assessment instrument used by Canadian academic libraries ${ }^{\text {ii. }}$

\section{Origin of the LibQUAL+ ${ }^{\mathrm{TM}}$ Canada Consortium}

At the June 2005 Annual General Meeting of the Canadian Association of Research Libraries (CARL) ${ }^{\mathrm{iii}}$, members expressed interest in coordinating LibQUAL+ ${ }^{\mathrm{TM}}$ participation in order to create a larger 


\section{LibQUAL Canada 2007: Service Quality Bench-marking on a National Scale}

database of Canadian content that would offer more meaningful benchmarking of services for Canadian academic research libraries. The CARL Committee on Effectiveness Measures and Statistics proposed a CARL-sponsored Canadian "consortial submission" to LibQUAL $+^{\mathrm{TM}}$ in 2007. I was appointed to head the consortial project.

When the survey opened in January 2007, 46 universities, 7 community colleges ${ }^{\text {iv }}$ and 3 federal government libraries from across Canada, had registered as members of the LibQUAL Canada Consortium. More significantly, $66 \%$ of the libraries had never done the survey including some smaller institutions who might not have considered using this service assessment tool on their own. A few other universities had initially joined the consortium but were not able to accommodate the survey program in their 2007 operations.

The members ranged from one of the largest universities in North America to small colleges. Our largest participant, the University of Toronto, registered each of its three campuses separately for the survey. At least two universities registered with a community college that shares the university's library facilities and services. One large member university (University of Alberta) does the survey annually. Notably, Alberta is also one of the very few Canadian libraries with a dedicated library assessment position.

A highly significant feature of the consortium was the need to represent the French-language, English and bilingual institutions. Although informal communication within the consortium was generally conducted in English, all of the consortium's documentation and announcements were bi-lingual as were all of the consortium's web pages. While ARL offers the basic survey questions in French most of the optional/local questions did not have French translations. The consortium took on the responsibility, on ARL's behalf, of ensuring that all the survey and demographic questions used by members of the consortium had correct Canadian French translations.

\section{Opportunities \& Challenges}

The opportunity to benchmark the library's services and programs with comparator Canadian institutions offering similar programs and services or within the same political/funding jurisdiction, was the consortium's most valuable primary purpose.

The consortium also offered its members:

- the opportunity to learn more about library assessment practice, including data collection, analysis and application in planning services, etc. within a supportive collegial environment;

- the opportunity for locally hosted workshops, including a pre-consortial survey workshop held in June 2006 in Ottawa and a 2007 national assessment conference/workshop in Ottawa to help participants communicate and apply their findings effectively;

Although the LibQUAL Canada Consortium was by far the largest LibQUAL+ ${ }^{\mathrm{TM}}$ consortium, it was the bilingual nature of the consortium that presented the greatest challenge. While ARL had French Canadian translations for the basic survey questions, the optional questions selected by the consortium had to be translated. In addition, the demographic data elements for U.S. government organizations 


\section{LibQUAL Canada 2007: Service Quality Bench-marking on a National Scale}

were inappropriate for the Canadian federal library members. The consortium worked with ARL to develop a custom Canadian government demographic and to translate it into French. In addition, ARL had never before integrated the survey results from two languages into consolidated sets of consortial results.

\section{Building the LibQUAL Canada Consortium}

What factors went into establishing and conducting this large and successful consortial project?

- Governance and Support. The 2007 project was funded through annual budget allocations from CARL in 2006 and 2007. My time, as coordinator, was seconded to the project by my employer. Ongoing operational support was provided by CARL staff, most notably by Katherine McColgan. The Project reported to the Association through the Chair of the Committee on Effectiveness Measures and Statistics, Mme. Sylvie Belzile. Ms. Belzile, Ms. McColgan and I comprised the informal project team. The project team met periodically by phone to review the progress of the project and I prepared written progress reports for the CARL directors at pre-established milestones throughout the project.

- Project Management Approach. Many participants were first-time participants; most did not have dedicated assessment staff to manage the process successfully on their own. By approaching the survey as a project, the consortium could guide its members through the planning process, via discrete, manageable sets of actions; each stage with its own timelines and deliverables. This approach was also important in coordinating the activities of all the consortium members throughout the planning and implementation process.

- Communication \& Engagement. My first action as Consortium Coordinator was to establish a moderated discussion/announcement list to which I subscribed each library contact. To maximize engagement, any librarian from a Canadian academic library was welcomed to join. Members were encouraged to contribute in shaping each phase of the project. Timelines and action items were revised at each stage based on member input. My highest priority was to ensure that every query was answered in a timely fashion and, in most cases, that the exchange was shared with the membership

- Active recruitment of participants. As persuasive as the benefits listed on the web site may have been, recruiting the broad range of participating libraries involved:

1. Building a critical mass. The Consortium sent invitations to the various library groups through their national and regional councils emphasizing the opportunity for peer benchmarking with libraries in the same regional/provincial jurisdiction. Follow-up announcements were sent to the councils, reporting who had signed up and encouraging others to enrol in the consortium. Once a critical mass of libraries from a region had joined, the regional councils (e.g. the Ontario Council of University Libraries) encouraged their other members to join the consortium. 


\section{LibQUAL Canada 2007: Service Quality Bench-marking on a National Scale}

2. Individual invitations and follow-up communication were sent to encourage maximum participation by leading institutions that other libraries tend to use as benchmarks.

3. Rapid response to queries from potential participants.

To assist them in persuading reluctant, wary administrators; in each case, we were able to supply the library with the information and documentation required to gain approval to participate, including documentation submitted by other Canadian academic libraries to gain research ethics board approval or exemption for their survey. The anonymous nature of the survey was certainly a consideration in gaining broad participation from the Canadian academic library community - particularly in a period when Canadian institutions were becoming concerned about the potential scrutiny of private Canadian data held in American databases, under the U.S. Patriot Act.

- Web Site. A major tool for recruiting members and for success of the project, was presenting the Canadian library community with a full-featured web site at the start of the project. While ARL's LibQUAL ${ }^{\mathrm{TM}}$ site contains a vast amount of useful information, its very size makes it a daunting resource to navigate.

The home page of the consortial site changed at key points in the life of the project. At the beginning of the project, the focus of the site was to attract participants and highlight the benefits of membership. During the planning and preparatory phases, the timeline became the primary link at the top of the navigation sidebar. After the survey closed, the consortial results page became the primary link in the navigation bar. The pages were continually updated throughout the project to maintain accurate timely access to resources for the members.

\section{Consortial Conferences \& Workshops ${ }^{v}$}

CARL, with invaluable support from ARL, sponsored two conference/workshops. The first was a one-day program, held in Ottawa in June 2006, in conjunction with the Canadian Library Association annual conference. The goals of the conference/workshop were to: (a) prepare consortium members to conduct the survey and (b) to recruit and inform prospective consortium members about the potential benefits of LibQUAL+ ${ }^{\mathrm{TM}}$ and the consortial project. The conference was very successful in meeting both goals. It attracted 60 delegates and the consortium grew by $30 \%$ after the program.

The second consortial conference had more ambitious goals. Held in Ottawa in October 2007, LibQUAL \& Beyond was a two-day stand-alone conference/workshop whose goals were: (a) to help consortium participants to analyze their LibQUAL $+^{\mathrm{TM}}$ results effectively; (b) to serve as a first Canadian library assessment conference; (c) to encourage libraries to use their LibQUAL+TM results and other kinds of assessment tools effectively, and start to build a "culture of assessment". The program was a great success, attracting 70 delegates from across Canada and engendering lively discussion. As significant as the actual program was the opportunity for delegates to meet other colleagues engaged in library assessment and talk about local practices, potential collaborations and what an "assessment librarian" actually does. 


\section{LibQUAL Canada 2007: Service Quality Bench-marking on a National Scale}

\section{Consortial Deliverables}

ARL Report Notebooks: ARL delivered the standard consortial results notebook with the aggregate data broken down by library type and user category. Within each group, the data was also broken down by survey language. In addition to the standard report notebook, the Consortium contracted with ARL to produce separate notebooks representing the aggregate results for CARL members, Ontario university libraries (OCUL), and Quebec university participants, Conférence des

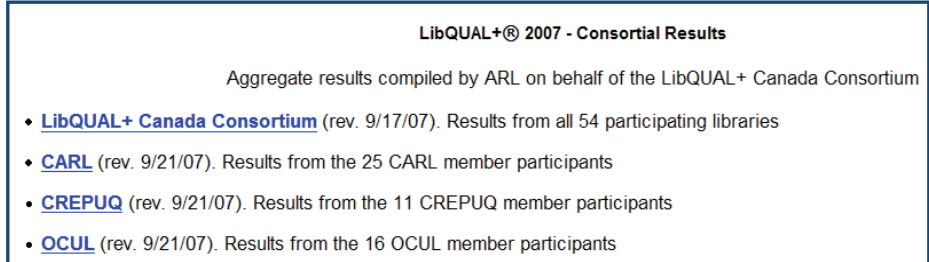
recteurs et des principaux des universités du Québec (CREPUQ).

The councils also approved my request to post the report notebooks on the LibQUAL Canada web site; making this data freely available to members and other researchers.

Data Sets: The consortium had received the complete data set representing the results for all 48,000 respondents. While it was important to provide the data to member libraries for comparative analysis, the consortium also wanted to protect the privacy of individual libraries who might not want to share their own library's raw data. So, the consortium made a pre-processed form of the consortial data available to its members to do their own analyses. Ron Ward, from the University of Guelph, kindly volunteered to prepare the data for distribution. The fields with individual identifiable data, such as the institution name, names of campus libraries, local discipline groups, etc. were replaced with masking codes. Subsets of the processed data were also generated by region (Atlantic Canada, Quebec, Ontario, Western Canada) to facilitate comparison. The processed data was made available to members upon request in SPSS or spreadsheet form.

The Consortium also offered to provide individual member libraries with the data set for their own library in SPSS form at no charge. ARL charges an additional fee if a library asks for its data in SPSS form after the initial LibQUAL+TM registration. The consortium was able to provide the data in SPSS form shortly after receiving the data in (CSV) spreadsheet format from ARL.

It is our goal to eventually make the complete masked SPSS data set available to all researchers in a searchable format.

\section{Future of the LibQUAL Canada Consortium}

On November 7, 2007, each LibQUAL Canada official contact was asked to complete a survey to assess whether 2007 participants would be interested in doing the survey again. If yes, how frequently and in what form.

With 48 of 54 member institutions having responded, the results ${ }^{\text {vi }}$ indicated that:

- $\quad 93.6 \%$ of our members wanted to take the LibQUAL+ ${ }^{\mathrm{TM}}$ survey again as members of the consortium. The remaining respondents were undecided for some of the reasons below.

- While $80 \%$ of respondents preferred the LibQUAL+ ${ }^{\mathrm{TM}}$ survey over developing a home-grown alternative, there was a slight preference among these respondents for a more abbreviated LibQUAL $+{ }^{\oplus}$ Lite survey instrument over the present 22 question-format. 


\section{LibQUAL Canada 2007: Service Quality Bench-marking on a National Scale}

- Regarding the frequency of future consortial surveys, members preferred to do the consortial survey every 2 or 3 years, with 53.5\% favouring the longer interval. While the registration fee was not mentioned as a major consideration, the demands on staff time required to plan the survey, review the results, analyze the implications for the library, prepare action plans to address concerns, etc. were often mentioned as concerns.

- While the consortium had excellent representation from Canadian universities, it offered more limited benchmarking value for the small number of community college participants. Adding to the benchmarking challenge for this group of libraries are the widely differing mandates of community colleges among the Canadian provinces, variously serving distance education students, continuing education, international students, students in certificate programmes, diploma programmes, academic programmes etc.

- The online consortial resources and other support generally received very high satisfaction scores for utility, responsiveness and timeliness. However, the ARL LibQUAL+ ${ }^{\mathrm{TM}}$ manual and the consortial web site did not offer sufficient guidance or examples relating to the needs of community colleges.

- Despite the strong support provided by the consortium, small academic institutions faced the challenge of finding sufficient staff time to assess their own results, review other best practices, plan and effect improvements to services and facilities. It is reasonable for such libraries to question whether to continue collecting LibQUAL ${ }^{\mathrm{TM}}$ data on a regular basis or only do the survey after they have the opportunity to act on the results. Typical of the small library comments was: We need an assessment librarian or someone who has more time to work with the results.

- There was uncertainty among our federal government participants as to the value of the consortium and perhaps the survey itself in meeting their special and diverse needs. The consortium had to work with ARL to develop a custom demographic for the Canadian government libraries to accommodate their many employee classifications and specific terminology. In additional to their small number, our government library members have very different mandates and user populations. One of our members, the Supreme Court of Canada Library, was investigating whether LibQUAL+ ${ }^{\mathrm{TM}}$ could be customized to the needs of a consortium of the Law Society and Courthouse Libraries in Canada.

\section{Conclusion}

The 48,000 consortial responses to the 2007 survey provided a rich new resource of assessment data for Canadian academic and research libraries. The availability of such a large data set offers Canadian library researchers a unique opportunity to study Canadian academic service quality data on a granular level not possible from individual library results or even from the combined results of the few past Canadian LibQUAL participants. This data set is large enough to provide opportunities to study potential difference in expectations and perceptions by gender, age, standard discipline group, undergraduate year, library type, region, etc. (e.g. $1^{\text {st }}$ year undergraduates or female graduate students in the humanities). 
This data may prove valuable to support advocacy efforts by academic library councils on behalf of their members, with governments and other funding sources.

When the consortium decides to conduct the survey again, probably in 2010 , we will have an additional set of valuable time-series data to help libraries assess the success of new cooperative initiatives and changes in client expectations and perceptions over time. 


\section{LibQUAL Canada 2007: Service Quality Bench-marking on a National Scale}

\section{References}

'McKenna, Julie and Jordan, Isla. Assessment Strategies FOR LIBRARY SERVICES

(http://www.accessola2.com/superconference2007/fri/1408/mckenna jordan.ppt)

ii Ibid.

iii CARL is an association of 30 research-intensive institutions; 27 universities, Library and Archives Canada, Canada Institute for Scientific and Technical Information (CISTI), and the Library of Parliament.

iv Canadian community colleges normally offer diploma and certificate programs, but not programs leading toward a university degree.

${ }^{\vee}$ The pre-survey http://library.queensu.ca/webir/canlibqual/carl-workshop.htm and post-survey http://library.queensu.ca/webir/canlibqual/carl-workshop-2007.htm conference programs and presentations are posted on the consortial web site.

${ }^{v i}$ http://library.queensu.ca/webir/canlibqual/consortial survey/SurveySummary.html 